\title{
A Stability Indicating Reverse Phase-HPLC Method Development and Validation for the Estimation of Rucaparib in Bulk and Pharmaceutical Dosage Form
}

\author{
D. Suchitra1, Satyanarayana Battu ${ }^{2 *}$ \\ ${ }^{1}$ Department of Pharmacy, University College of Technology, Osmania University, Hyderabad, India \\ ${ }^{2}$ Department of Chemistry, University College of Science, Osmania University, Hyderabad, India \\ Email: suchirakhi@gmail.com, *satyambchem@yahoo.co.in
}

How to cite this paper: Suchitra, D. and Battu, S. (2021) A Stability Indicating Reverse Phase-HPLC Method Development and Validation for the Estimation of Rucaparib in Bulk and Pharmaceutical Dosage Form. American Journal of Analytical Chemistry, 12, 96-107.

https://doi.org/10.4236/ajac.2021.124008

Received: March 19, 2021

Accepted: April 23, 2021

Published: April 26, 2021

Copyright $\odot 2021$ by author(s) and Scientific Research Publishing Inc. This work is licensed under the Creative Commons Attribution International License (CC BY 4.0).

http://creativecommons.org/licenses/by/4.0/

\begin{abstract}
The research was carried out for establishing a new reverse phase-HPLC stability indicating method for the quantification of Rucaparib. The experiment was determined on Waters HPLC instrument using 996 photo-diode array detector. The separation was done by using symmetry C-18 ODS $(25 \mathrm{~cm} \times$ $0.46 \mathrm{~cm}$ internal diameter) $5 \mu \mathrm{m}$ analytical column containing mobile phase of Phosphate buffer $(0.02 \mathrm{M})$ and methanol [65:35\% v/v] adjusted $\mathrm{pH}$ to 4.8 by adding dilute ortho phosphoric acid. The method was run at $1 \mathrm{ml} \cdot \mathrm{min}^{-1}$ at $286 \mathrm{~nm}$ detection. The drug was eluted at $5.484 \mathrm{~min}$. After developing the method, it was assured for the intended use by validation which was done according to ICH Q2B guidelines. The analytical parameters checked were linearity, accuracy, repeatability, intermediate precision, limit of detection, limit of quantitation, ruggedness and robustness. It was observed that the response of the detector was linear in the range of $6-14 \mu \mathrm{g} / \mathrm{ml}$ with correlation coefficient of 0.999 . The results of all the parameters were found to be within the acceptance criteria. The stability indicating assay method was established by using the samples generated by forced degradation process. The forced degradation was carried out by subjecting the drug to acid, alkali, thermal, oxidative and photolytic degradation and the results showed that the degradation products were successfully separated from the drug. Hence, this can be applied perfectly later for the analysis of quality of the rucaparib drug.
\end{abstract}

\section{Keywords}

Rucaparib, Reverse-Phase High Performance Liquid Chromatography, Method Development, Validation 


\section{Introduction}

Rucaparib chemically, 8-fluoro-2-\{4-[(methylamino) methyl] phenyl\}-1,3,4,5tetrahydro-6H-azepino[5,4,3-cd] indol-6-one is a small molecule inhibitor of Poly ADP-Ribose Polymerase (PARP) which is used for treating patients with refractory and advanced carcinoma. It is the best targeting first-in-class drug on PARP 1, 2 and 3 DNA repair enzyme. Upon administration, it selectively binds to PARP-1,2 and 3 receptors for inhibiting the DNA repairing mechanism by PARP enzyme. Thus, it leads to breaking of DNA strands, causes genomic instability, arrest cell cycle and finally apoptosis [1].

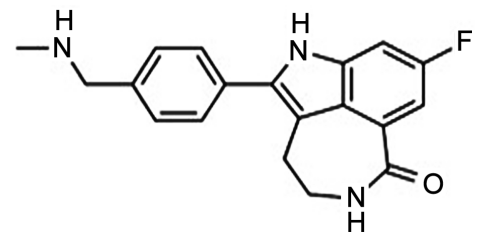

The complete information with data supplemented from the literature that there are only few methods like LC-MS/MS [2] [3] [4] [5] techniques which are very expensive but there was no simple method developed till date for the analysis of Rucaparib drug. Hence, it felt necessary to establish a new, easier, cost effective, precise, accurate and specific stability indicating analytical method which can be easily applicable for routine drug performance evaluations.

\section{Materials and Methods}

\subsection{Materials}

The investigated sample Rucaparib [Maxheal Pharmaceutical Pvt. Ltd.] was procured from local market, Hyderabad. The standard Rucaparib drug was procured from Sanzyme Ltd. Acetonitrile [Merck], Methanol [Merck], Triethylamine [Merck], Water [Merck], Potassium dihydrogen phosphate were of HPLC grade.

\subsection{Equipment}

Waters HPLC system equipped with 996 photo diode array detector was used for quantitation of Rucaparib. The processing with complete data obtained from Empower 2 software. The samples solubility in mobile phase was enhanced using Sonicator (SE60US model) Labman company. All the samples prepared were filtered using Vacuum filtration kit made by Labman.

\section{Methodology}

\subsection{Chromatographic Conditions}

The reverse-phase chromatography was performed on Waters HPLC using 996 photo diode array detection. The separation was done by using symmetry C18 ODS $(25 \mathrm{~cm} \times 0.46 \mathrm{~cm}$ internal diameter $) 5 \mu \mathrm{m}$ analytical column containing 
Phosphate buffer $(0.02 \mathrm{M})$ and Methanol [65:35\% v/v] mobile phase, adjusted the $\mathrm{pH}$ to 4.8 by dilute ortho phosphoric acid solution. The method was run at 1 $\mathrm{ml} \cdot \mathrm{min}^{-1}$ at $286 \mathrm{~nm}$ UV detection. The elution time for Rucaparib drug was at $5.484 \mathrm{~min}$.

\subsection{Preparation of Rucaparib Stock and Working Stock Solutions}

Accurately weighed $10 \mathrm{mg}$ of Rucaparib standard drug was taken into $10 \mathrm{ml}$ volumetric flask, diluted to volume and mixed thoroughly by ultrasonication in order to enhance solubility and to degas the solutions. From the stock solution $0.1 \mathrm{ml}$ was pipetted into $10 \mathrm{ml}$ volumetric flask, diluted to volume mixed thoroughly, treated with $0.45 \mu \mathrm{l}$ filter paper and finally sonicated for $15 \mathrm{~min}$. The prepared solution was introduced into the flow stream of mobile phase and recorded chromatograms. After so many experimental trials, the successful separation was achieved. Noted the optimized conditions and proceeded for validation as per ICH guidelines.

\subsection{Preparation of Sample Solution}

Twenty tablets of Rubraca (300 mg) were made into fine powder using mortar and pestle. From this, an amount equivalent to $10 \mathrm{mg}$ was taken into clean dry volumetric flask [10 ml], diluted to volume, treated with $0.45 \mu \mathrm{l}$ filter paper and sonicated for $15 \mathrm{~min}$. From this, further pipetted out $0.1 \mathrm{ml}$ solution, diluted to volume and mixed thoroughly. Injected the standard and sample solutions in triplicates and the \% assay was calculated.

\section{Method Validation}

As per ICH guidelines [6] [7] the checked validation parameters were accuracy, precision, linearity, LOD, LOQ, robustness and specificity [8].

\subsection{System Suitability}

For evaluating the suitability of HPLC system and procedure, the Rucaparib standard solution of $10 \mu \mathrm{g} \mathrm{ml}^{-1}$ concentration of about $20 \mu \mathrm{l}$ was introduced into the HPLC system and recorded the chromatogram.

\subsection{Accuracy}

In order to determine the method's accuracy, the drug was spiked at 50\%, 100\% and $150 \%$ levels. The chromatograms were recorded and noted the peak areas. From this, the average recovery of analyte was calculated.

\subsection{Precision}

Intra-day assay and intermediate precision were evaluated to determine method's precision.

\subsubsection{Intra-Day Assay Precision}

To evaluate the intra-day precision, $10 \mu \mathrm{g} / \mathrm{ml}$ concentration solution was in- 
jected for five times under unchanged conditions within a short period of time. The peak areas for the five replicate injections were collected and calculated the \% Relative standard deviation.

\subsubsection{Intermediate Precision}

To evaluate the Intermediate precision, the sample was analyzed on different days under unchanged conditions. Collected the peak areas and calculated the \% Relative standard deviation.

\subsection{Linearity}

The linearity was evaluated by injecting over the range of $6-14 \mu \mathrm{g} / \mathrm{ml}$ concentration solutions of Rucaparib. A calibration curve was plotted between analyte concentration and analyte response. Performed regression analysis using least square method and calculated the correlation coefficient (r).

\subsection{Robustness}

Robustness was evaluated by slightly changing the chromatographic conditions which includes percent organic solvent and flow rate.

\subsubsection{Effect of Slight Change in Flow Rate}

The Rucaparib solution was analysed at $0.9 \mathrm{ml} \cdot \mathrm{min}^{-1}$ and $1.1 \mathrm{ml} \cdot \mathrm{min}^{-1}$ rather than optimized flow rate of $1.0 \mathrm{ml} \cdot \mathrm{min}^{-1}$. Chromatograms were collected to compare with optimized chromatographic conditions.

\subsubsection{Effect of Slight Changes in Percent Organic Solvent}

The Rucaparib solution was analysed by slightly varying the percent organic solvent i.e., Phosphate buffer and Methanol as 60:40 and 70:30 ratios rather than $65: 35 \mathrm{v} / \mathrm{v}$. Chromatograms were collected to compare with optimized chromatographic conditions.

\subsection{Limit of Detection}

The formula used to determine the lowest amount of analyte was,

LOD $=3.3 \times$ standard deviation of response/slope of the calibration curve

\subsection{Limit of Quantitation}

The formula used to calculate the quantitation limit was,

LOQ $=10 \times$ standard deviation of response/slope of the calibration curve.

\section{Forced Degradation Studies}

The stress testing was carried out to generate samples for establishing the stability indicating assay method by treating the Rucaparib solution to extreme conditions such as acidic, basic, peroxide, thermal, ultraviolet and water degradation. Chromatograms were recorded and purity of the peak was determined by calculating the $\%$ of degraded amount and $\%$ of active amount. 


\subsection{Acid Degradation}

Taken $1 \mathrm{ml}$ of Rucaparib stock solution and $1 \mathrm{ml}$ of $2 \mathrm{~N} \mathrm{HCl}$, refluxed for $30 \mathrm{~min}$ at $60^{\circ} \mathrm{C}$. Later it was neutralized with $1 \mathrm{ml} 2 \mathrm{~N} \mathrm{NaOH}$ and made up to final volume to obtain $10 \mu \mathrm{g} \cdot \mathrm{ml}^{-1}$ solution. Cooled to the room temperature and treated with $0.45 \mu \mathrm{l}$ membrane filter. $20 \mu \mathrm{l}$ sample was introduced into the HPLC system and recorded the chromatogram.

\subsection{Basic Degradation}

Taken $1 \mathrm{ml}$ of Rucaparib stock solution and $1 \mathrm{ml}$ of $2 \mathrm{~N}$ Sodium hydroxide, refluxed for $30 \mathrm{~min}$ at $60^{\circ} \mathrm{C}$. Later it was neutralized with $1 \mathrm{ml} 2 \mathrm{~N} \mathrm{HCl}$ and made up to the final volume to obtain $10 \mu \mathrm{g} \cdot \mathrm{ml}^{-1}$ solution. Cooled to the room temperature and treated with $0.45 \mu \mathrm{m}$ membrane filter. $20 \mu \mathrm{l}$ sample was introduced into system, and recorded the chromatogram.

\subsection{Oxidative Degradation}

Taken $1 \mathrm{ml}$ of Rucaparib stock solution and $1 \mathrm{ml}$ of $20 \%$ hydrogen peroxide $\left(\mathrm{H}_{2} \mathrm{O}_{2}\right)$ and left for $30 \mathrm{~min}$ at $60^{\circ} \mathrm{C}$. Later the solution was made up to the final volume to get $10 \mu \mathrm{g} \cdot \mathrm{ml}^{-1}$ solution. Cooled to room temperature, treated with 0.45 $\mu \mathrm{m}$ membrane filter. Finally, $20 \mu \mathrm{l}$ sample was introduced into the HPLC system, and recorded the chromatogram.

\subsection{Thermal Degradation}

Kept $1 \mathrm{ml}$ of Rucaparib stock solution in an oven at $60^{\circ} \mathrm{C}$ for $6 \mathrm{hrs}$ and made up to final volume to get $10 \mu \mathrm{g} \cdot \mathrm{ml}^{-1}$ concentration. Cooled to room temperature and treated with $0.45 \mu \mathrm{m}$ member filter. Later, $20 \mu \mathrm{l}$ sample solution was introduced into the HPLC system and recorded the chromatogram.

\subsection{Photo Degradation}

$1 \mathrm{ml}$ of stock solution of Rucaparib was exposed to Ultra-violet light for 1 day and made up to final volume to get $10 \mu \mathrm{g} \cdot \mathrm{ml}^{-1}$ concentration and treated with $0.45 \mu \mathrm{m}$ membrane filter. Later $20 \mu \mathrm{l}$ sample solution was introduced into the HPLC system and recorded the chromatogram.

\section{Results and Discussions}

\subsection{Method Development}

For this method development, various ratios and combination of mobile phases, different stationary phases and flow rates were tried to elute the drug with good peak parameters and to provide good performance in assay. Finally, the best separation was achieved on symmetry C18 ODS column $(250 \mathrm{~mm} \times 4.6 \mathrm{~mm}$ id, 5 $\mu \mathrm{m})$ comprising mobile phase of phosphate buffer (0.02M): Methanol [65:35\% $\mathrm{v} / \mathrm{v}$, adjusted the $\mathrm{pH}$ to 4.8 by dilute ortho phosphoric acid. The method was run at a flow rate of $1.0 \mathrm{ml} \cdot \mathrm{min}^{-1}$ and the eluent was detected at $5.484 \mathrm{~min}$ by UV detector at $286 \mathrm{~nm}$. The chromatogram showed the peak with good shape, 
more theoretical plates and the tailing factor was also found to be within the limits. All the method development trials with various mobile phase compositions, columns and flow rates results were shown in Table 1. The standard chromatogram of rucaparib drug was presented in Figure 1.

\subsection{Analytical Method Validation}

\subsubsection{System Suitability}

The theoretical plate number, peak asymmetry and percentage relative standard deviation obtained are within the acceptance criteria and demonstrated that the method can generate the accurate and precise results. The results were presented in Table 2.

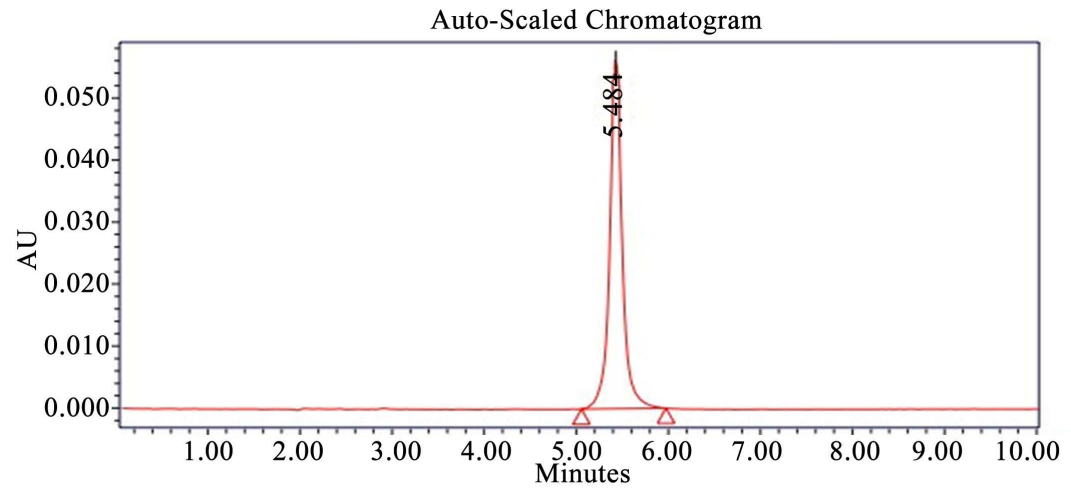

Figure 1. Optimized chromatogram (standard) of Rucaparib.

Table 1. Method development trials and observation.

\begin{tabular}{|c|c|c|c|c|c|}
\hline \multirow{2}{*}{$\begin{array}{l}\text { Trials } \\
\text { S. No. }\end{array}$} & \multicolumn{5}{|c|}{ Chromatographic conditions } \\
\hline & Analytical Column & $\begin{array}{l}\text { Mobile phase } \\
\text { composition }\end{array}$ & $\begin{array}{l}\text { Flow } \\
\text { rate }\end{array}$ & $\begin{array}{l}\text { Retention } \\
\text { time (min) }\end{array}$ & Result \\
\hline 1 & $\begin{array}{c}\text { Inertsil C18 } \\
(15 \mathrm{~cm} \times 0.46 \mathrm{~cm}) 5 \mu \mathrm{m}\end{array}$ & $\begin{array}{l}\text { Water: Methanol } \\
(50: 50 \% \mathrm{v} / \mathrm{v})\end{array}$ & $0.8 \mathrm{ml} / \mathrm{min}$ & 7.553 & $\begin{array}{l}\text { Improper peak } \\
\text { separation } \\
\text { and more RT. }\end{array}$ \\
\hline 2 & $\begin{array}{c}\text { Zodiac C18 } \\
(4.6 \times 150 \mathrm{~mm}) 5 \mu \mathrm{m}\end{array}$ & $\begin{array}{l}\text { ACN: } \mathrm{MeOH} \\
(40: 60 \%) \mathrm{v} / \mathrm{v}\end{array}$ & $0.9 \mathrm{ml} / \mathrm{min}$ & 2.508 & $\begin{array}{l}\text { Improper peak } \\
\text { separation and } \\
\text { less plate count. }\end{array}$ \\
\hline 3 & $\begin{array}{c}\text { Develosil C18 } \\
(4.6 \times 150 \mathrm{~mm}) 5 \mu \mathrm{m}\end{array}$ & $\begin{array}{c}\text { ACN: } 0.1 \% \text { OPA } \\
(\mathrm{pH}-3.6) \\
(30: 70) \mathrm{v} / \mathrm{v}\end{array}$ & $1.0 \mathrm{ml} / \mathrm{min}$ & 3.213 & $\begin{array}{l}\text { Improper peak } \\
\text { separation and } \\
\text { less plate count. }\end{array}$ \\
\hline 4 & $\begin{array}{l}\text { Phenomenex C18 ODS } \\
(4.6 \times 150 \mathrm{~mm}) 5 \mu \mathrm{m}\end{array}$ & $\begin{array}{c}\text { ACN: Ammonium } \\
\text { buffer }(0.1 \mathrm{M}) \\
(45: 55 \% \mathrm{v} / \mathrm{v})\end{array}$ & $1.0 \mathrm{ml} / \mathrm{min}$ & 3.213 & $\begin{array}{c}\text { Improper peak } \\
\text { separation, more } \\
\text { tailing and less } \\
\text { plate count. }\end{array}$ \\
\hline 5 & $\begin{array}{l}\text { Symmetry C18 ODS } \\
(4.6 \times 150 \mathrm{~mm}) 5 \mu \mathrm{m}\end{array}$ & $\begin{array}{c}\text { MeOH: Phosphate } \\
\text { buffer }(0.01 \mathrm{M}) \\
(40: 60 \%) \mathrm{v} / \mathrm{v}\end{array}$ & $1.0 \mathrm{ml} / \mathrm{min}$ & 4.161 & $\begin{array}{l}\text { Improper peak } \\
\text { separation and } \\
\text { peak broadening. }\end{array}$ \\
\hline 6 & $\begin{array}{l}\text { Symmetry C18 ODS } \\
(4.6 \times 150 \mathrm{~mm}) 5 \mu \mathrm{m}\end{array}$ & $\begin{array}{c}\text { MeOH: Phosphate } \\
\text { buffer }(0.05 \mathrm{M}) \\
(20: 80 \%) \mathrm{v} / \mathrm{v}\end{array}$ & $1.0 \mathrm{ml} / \mathrm{min}$ & 4.396 & $\begin{array}{l}\text { Improper peak } \\
\text { separation, broad } \\
\text { peak and } \\
\text { peak tailing. }\end{array}$ \\
\hline
\end{tabular}


Table 2. System suitability data.

\begin{tabular}{ccc}
\hline S. No. & Parameters & Rucaparib \\
\hline 1. & Rt (min) & 5.482 \\
2. & Plate count & 6967 \\
3. & Asymmetry & 1.12 \\
4. & Peak Area (AUC) & 647856 \\
\hline
\end{tabular}

\subsubsection{Accuracy}

It was found that the average recovery at $50 \%, 100 \%$, and $150 \%$ were found to be within the limits which indicated the methods Accuracy. The measured results were provided in Table 3.

\subsubsection{Precision}

The \% RSD obtained was within the limits indicating the methods precision. Tables 4-6 depicts the results of intraday precision and intermediate precision respectively.

\subsubsection{Linearity}

The method exhibited linearity in the range of 6 to $14 \mu \mathrm{g} \cdot \mathrm{ml}^{-1}$. The obtained data was statistically analysed and results were presented in Table 7 and the calibration curve was depicted in Figure 2.

\subsubsection{Robustness}

Upon slight changes in the flow rate and percent organic solvent, the results confirmed the reliability of the method. Results were presented in Table 8.

\subsubsection{Limit of Detection (LOD) and Limit of Quantitation (LOQ)}

The calculated LOD and LOQ values of rucaparib are $0.49 \mu \mathrm{g} \cdot \mathrm{ml}^{-1}$ and 1.486 $\mu \mathrm{g} \cdot \mathrm{ml}^{-1}$ respectively.

\subsubsection{Assay Determination of Rucaparib}

The \% purity of Rucaparib present in the marketed formulation was found to be 99.328\%. The assay results of standard and marketed formulation of rucaparib were shown in Table 9 and Table 10 respectively.

\subsubsection{Forced Degradation Studies}

The forced degradation results showed that the rucaparib drug was found to be liable to acid and degraded to about $17.24 \%$. In basic degradation, it was found to be degraded to about $16.18 \%$. Upon oxidation, it was degraded to about $14.06 \%$ and in thermal degradation to about $13.59 \%$. Very less degradation was observed in photolytic degradation to about $5.38 \%$. According to FDA guidance, for the validation of any chromatographic assay $5 \%$ to $20 \%$ of degradation is acceptable. Therefore, in the present method the \% degraded amount is within the specified limits and moreover, the successful separation of active pharmaceutical product from degradation products without any interference proved the stability indicating nature. The obtained chromatograms during stress testing were depicted in Figures 3-7. The measured values are provided in Table 11. 


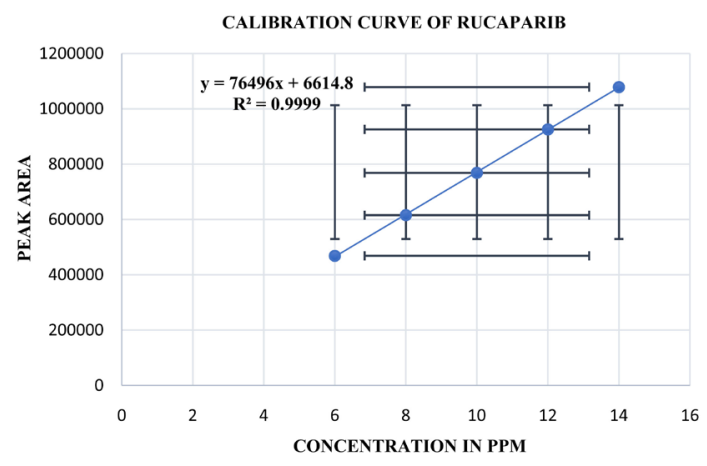

Figure 2. Calibration curve of Rucaparib.

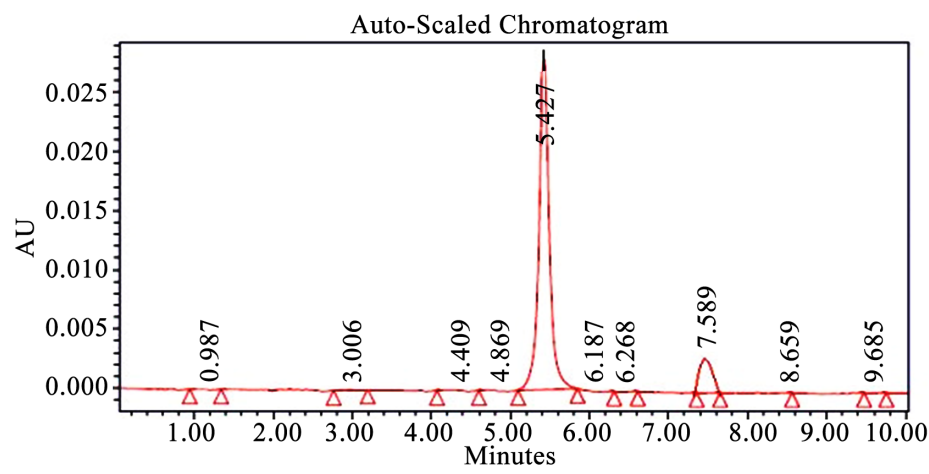

Figure 3. Acid degradation chromatogram of Rucaparib.

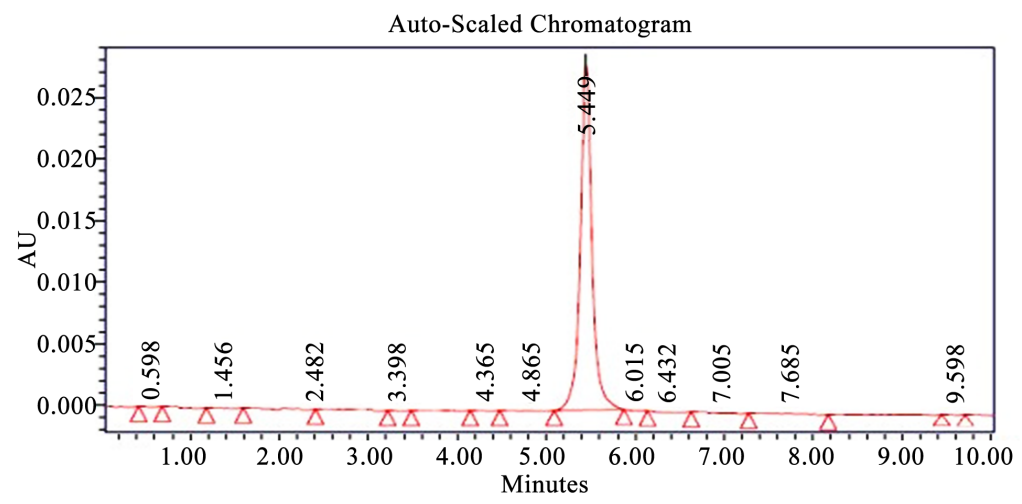

Figure 4. Basic degradation chromatogram of Rucaparib.

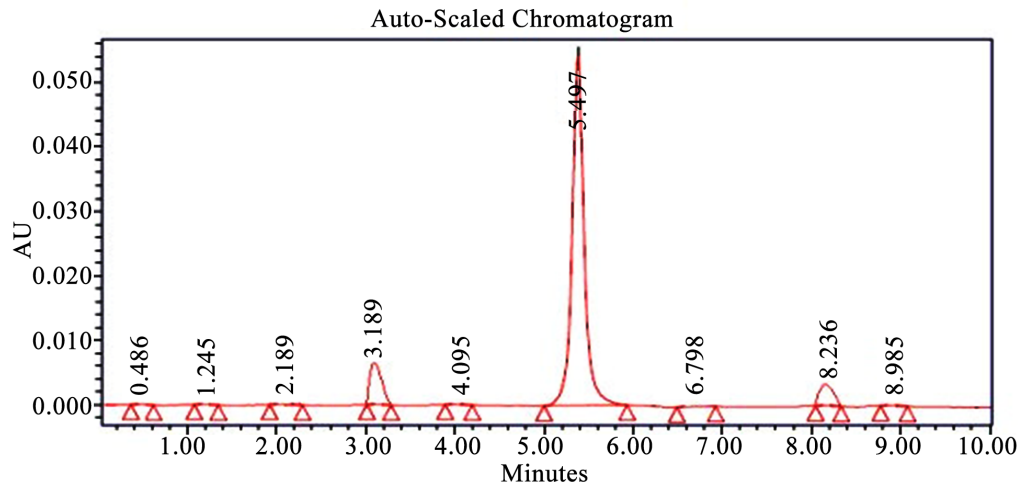

Figure 5. Oxidative degradation chromatogram of Rucaparib. 


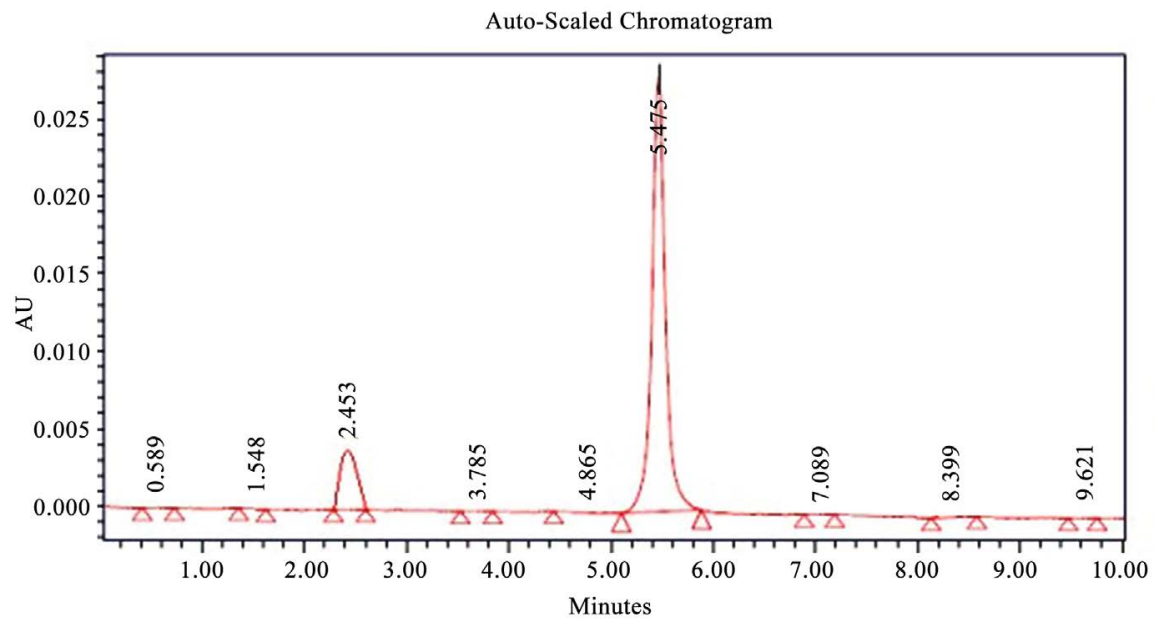

Figure 6. Thermal degradation chromatogram of Rucaparib.

Table 3. Rucaparib recovery data.

\begin{tabular}{|c|c|c|c|c|c|c|}
\hline Spiking level & Peak Areas & $\begin{array}{c}\text { Average } \\
\text { Area }\end{array}$ & $\begin{array}{c}\text { Spiked } \\
\text { concentration } \\
(\mathrm{ppm})\end{array}$ & $\begin{array}{c}\text { Found } \\
\text { concentration } \\
(\mathrm{ppm})\end{array}$ & $\begin{array}{c}\text { Percentage } \\
\text { Recovery }\end{array}$ & $\begin{array}{l}\text { Average } \\
\text { Recovery }\end{array}$ \\
\hline & 387,568 & & & & & \\
\hline \multirow[t]{3}{*}{$50 \%$} & 385,246 & 386,559 & 5 & 5 & $100.000 \%$ & \\
\hline & 386,863 & & & & & \\
\hline & 768,796 & & & & & \\
\hline \multirow[t]{3}{*}{$100 \%$} & 768,354 & 768,536 & 10 & 9.965 & $99.650 \%$ & $100.130 \%$ \\
\hline & 768,458 & & & & & \\
\hline & $1,165,247$ & & & & & \\
\hline \multirow[t]{2}{*}{$150 \%$} & $1,163,586$ & $1,164,522$ & 15 & 15.111 & $100.740 \%$ & \\
\hline & $1,164,732$ & & & & & \\
\hline
\end{tabular}

Table 4. Intra-day precision data of Rucaparib.

\begin{tabular}{cccccc}
\hline \multirow{2}{*}{ Drug } & S. No. & $\begin{array}{c}\text { Retention } \\
\text { time (min) }\end{array}$ & $\begin{array}{c}\text { Peak } \\
\text { Area }\end{array}$ & $\begin{array}{c}\text { No. of } \\
\text { Theoretical plates }\end{array}$ & Asymmetry \\
\hline 1 & 5.419 & 645,784 & 6825 & 1.05 \\
2 & 5.405 & 642,589 & 6849 & 1.09 \\
3 & 5.478 & 643,658 & 6845 & 1.08 \\
Rucaparib & 5.466 & 648,759 & 6839 & 1.09 \\
& 5 & 5.466 & 647,854 & 6874 & 1.10 \\
& & 645,729 & & \\
Mean & & 2638.569 & & \\
SD & & 0.408619 & & \\
\% Relative & & & & \\
standard deviation & & & & \\
\hline
\end{tabular}




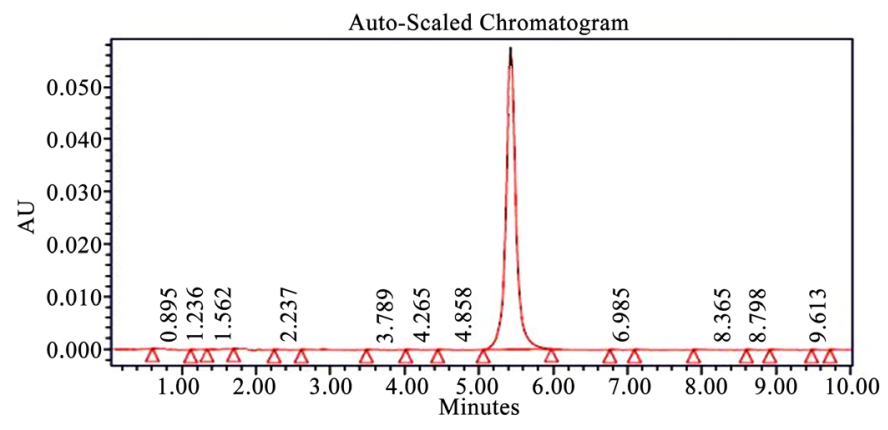

Figure 7. Photolytic degradation chromatogram of Rucaparib.

Table 5. Day 1 Intermediate precision data of Rucaparib.

\begin{tabular}{cccccc}
\hline Drug & S. No. & $\begin{array}{c}\text { Retention } \\
\text { Time (min) }\end{array}$ & $\begin{array}{c}\text { Peak } \\
\text { Area }\end{array}$ & $\begin{array}{c}\text { No. of } \\
\text { theoretical plates }\end{array}$ & $\begin{array}{c}\text { Peak } \\
\text { Asymmetry }\end{array}$ \\
\hline 1 & 5.484 & 636,854 & 6758 & 1.09 \\
2 & 5.493 & 637,489 & 6726 & 1.08 \\
3 & 5.406 & 635,762 & 6749 & 1.09 \\
4 & 5.419 & 636,984 & 6698 & 1.07 \\
Rucaparib & 5.446 & 634,856 & 6728 & 1.08 \\
& 6 & 5.452 & 639,689 & 6699 & 1.08 \\
& & 636,939 & & \\
Mean & & 1649.149 & & \\
\hline
\end{tabular}

Table 6. Day 2 Intermediate precision data of Rucaparib.

\begin{tabular}{cccccc}
\hline \multirow{2}{*}{ Drug } & S. No. & $\begin{array}{c}\text { Retention } \\
\text { Time (min) }\end{array}$ & $\begin{array}{c}\text { Peak } \\
\text { Area }\end{array}$ & $\begin{array}{c}\text { No. of } \\
\text { Theoretical plates }\end{array}$ & $\begin{array}{c}\text { Peak } \\
\text { Asymmetry }\end{array}$ \\
\hline 1 & 5.491 & 628,985 & 6985 & 1.09 \\
& 2 & 5.482 & 624,879 & 6899 & 1.07 \\
Rucaparib & 5 & 5.416 & 625,846 & 6928 & 1.06 \\
& 5 & 5.482 & 623,568 & 6874 & 1.09 \\
& 6 & 5.495 & 628,985 & 6984 & 1.07 \\
& & 5.427 & 628,473 & 6872 & 1.08 \\
& Mean & & $626,789.3$ & & \\
& Standard Deviation. & & 2340.636 & & \\
\hline
\end{tabular}

Table 7. Linearity data of Rucaparib.

\begin{tabular}{ccc}
\hline S. No. & Concentration $(\mu \mathrm{g} / \mathrm{ml})$ & Peak Area \\
\hline $\mathbf{1}$ & 6 & 468,784 \\
2 & 8 & 615,798 \\
$\mathbf{3}$ & 10 & 768,759 \\
$\mathbf{4}$ & 12 & 925,748 \\
$\mathbf{5}$ & 14 & $1,078,765$ \\
Mean & - & $771,570.8$ \\
SD & - & $216,375.5$ \\
\hline
\end{tabular}


Table 8. Robustness data of Rucaparib.

\begin{tabular}{ccccc}
\hline Parameters & $\begin{array}{c}\text { Peak } \\
\text { Area }\end{array}$ & $\begin{array}{c}\text { Retention } \\
\text { Time }(\mathrm{min})\end{array}$ & $\begin{array}{c}\text { Theoretical } \\
\text { plates }\end{array}$ & $\begin{array}{c}\text { Peak } \\
\text { Asymmetry }\end{array}$ \\
\hline Optimized flow rate of $1.0 \mathrm{~mL} \cdot \mathrm{min}^{-1}$ & 648,759 & 5.484 & 6845 & 1.08 \\
At $0.9 \mathrm{~mL} \cdot \mathrm{min}^{-1}$ flow conditions & 635,248 & 5.599 & 6786 & 1.09 \\
At 1.1 $\mathrm{mL} \cdot \mathrm{min}^{-1}$ flow conditions & 659,865 & 4.576 & 6528 & 1.05 \\
Lesser percent organic solvent & 625,986 & 7.415 & 6689 & 1.03 \\
Higher percent organic solvent & 615,869 & 3.827 & 6354 & 1.01 \\
\hline
\end{tabular}

Table 9. Assay data of standard rucaparib drug.

\begin{tabular}{ccccc}
\hline S. No. & Retention Time & Peak Area & Asymmetry & No. of Theoretical plates \\
\hline 1 & 5.427 & 647598 & 1.09 & 6895 \\
2 & 5.430 & 648759 & 1.10 & 6826 \\
3 & 5.443 & 649856 & 1.08 & 6863 \\
\hline
\end{tabular}

Table 10. Assay data of marketed formulation.

\begin{tabular}{cccccc}
\hline Drug & S. No. & Retention Time & Peak Area & Asymmetry & No. of Theoretical plates \\
\hline \multirow{3}{*}{ Rucaparib } & 1 & 5.453 & 658,754 & 1.12 & 6859 \\
& 2 & 5.462 & 656,842 & 1.13 & 6873 \\
& 3 & 5.466 & 657,895 & 1.12 & 6829 \\
\hline
\end{tabular}

Table 11. Forced degradation studies data for Rucaparib.

\begin{tabular}{cccccc}
\hline S. No. & $\begin{array}{c}\text { Stress } \\
\text { Condition }\end{array}$ & $\begin{array}{c}\text { Peak } \\
\text { Area }\end{array}$ & $\begin{array}{c}\text { \% of Degraded } \\
\text { Amount }\end{array}$ & $\begin{array}{c}\text { \% of Active } \\
\text { Amount }\end{array}$ & $\begin{array}{c}\text { Total \% of } \\
\text { Amount }\end{array}$ \\
\hline 1 & Standard & 648,759 & 0 & $100 \%$ & $100 \%$ \\
2 & Acidic & $536,912.94$ & 17.24 & 82.76 & $100 \%$ \\
3 & Basic & $543,789.79$ & 16.18 & 83.82 & $100 \%$ \\
4 & Oxidative & $557,543.48$ & 14.06 & 85.94 & $100 \%$ \\
5 & Thermal & $560,592.65$ & 13.59 & 86.41 & $100 \%$ \\
6 & Photolytic & $613,855.76$ & 5.38 & 94.62 & $100 \%$ \\
\hline
\end{tabular}

\section{Conclusion}

The present established stability indicating Reverse phased High-performance liquid chromatographic method is new, fast and easier to quantify the Rucaparib drug with precise and accurate results. The successful separation of all the degradation products from the active pharmaceutical ingredient proved the specificity and the stability indicating nature of the developed method. In comparison to the reported method for the identification and quantification of degraded impurities by HPLC and characterization by LC-MS technique, where the Rucaparib showed the retention time at $11.9 \mathrm{~min}$ and the detection limit was 11 $\mu \mathrm{g} / \mathrm{ml}$, the present developed method requires lesser analysis time and more sensitive, showing the retention time of $5.484 \mathrm{~min}$ and detection limit of $0.49 \mu \mathrm{g} / \mathrm{ml}$. 
Thus, the shorter duration of analysis time, more sensitivity and cost effectiveness revealed that it is suitably applied for routine laboratory use.

\section{Conflicts of Interest}

The authors declare no conflicts of interest regarding the publication of this paper.

\section{References}

[1] https://pubchem.ncbi.nlm.nih.gov

[2] Vamseekrishna, G., Ajay Kumar, G. and Chowdary, Y.A. (2018) A Sensitive Bio Analytical Method Development and Validation of Rucaparib in Human Plasma by LC-ESI-MS/MS. International Journal of Advanced Research, 6, 836-843. https://doi.org/10.21474/IJAR01/6290

[3] Sparidans Rolf, W., Selvi, D., Schellens, A.H. and Beijnen, J.H. (2014) Liquid Chromatography-Tandem Mass Spectrometric Analysis for the PARP Inhibitor Rucaparib in Plasma. Journal of Pharmaceutical and Biomedical Analysis, 88, 626-629. https://doi.org/10.1016/j.jpba.2013.10.016

[4] Palakeeti, B., Ramesh, T., Vijender Reddy, K., Ramaiah, K., et al. (2019) Identification and Characterization of Rucaparib Degradation Products and Their Comparision with Known Impurities. Chromatographia, 82, 591-604. https://doi.org/10.1007/s10337-018-3669-Z

[5] Bruin, M.A.C., de Vries, N., Lucas, L., Rosing, H., Huitema, A.D.R. and Beijnen, J.H. (2020) Development and Validation of an Integrated LC-MS/MS, Assay for Therapeutic Drug Monitoring of Five PARP-Inhibitors. Journal of Chromatography $B, 1138,121925$. https://doi.org/10.1016/j.jchromb.2019.121925

[6] ICH, Q2B, International Conference on Harmonization (1996) Validation of Analytical Procedures, Methodology.

[7] International Conference on Harmonization, ICH Q1A $\left(\mathrm{R}_{2}\right)$ (2002) Stability Testing of New Drug substances and Products.

[8] Snyder, L.R., Kirkland, J.J. and Glanch, J.L. (1997) Practical HPLC Method Development, Second Edition. https://doi.org/10.1002/9781118592014 